\title{
COMPARATIVE SOCIAL MEDIA ANALYSIS OF THE ART GALLERIES IN TURKEY
}

\author{
Hanzade URALMAN \\ Okan University, Türkiye \\ hanzade.uralman@okan.edu.tr \\ https://orcid.org/0000-0001-6817-7097 \\ Deniz AKÇAY \\ İstanbul Gedik University, Türkiye \\ akcay.deniz78@gmail.com \\ https://orcid.org/0000-0003-1906-7988
}

\author{
Atıf \\ Uralman, H. \& Akçay, D. (2022). Comparative Social Media Analysis of The Art Galleries in \\ Turkey. The Turkish Online Journal of Design Art and Communication, 12 (2), 334-349.
}

\begin{abstract}
Art marketing aims to sell art works and create areas of artistic experience offering value to the people. As a part of the art industry, art galleries also use social media for this purpose in their marketing efforts. In this respect, social media for art galleries is a digital platform that bridges the gap between artists, collectors and those interested in buying or in viewing art. In this respect, it is a research topic how art galleries can use this platform effectively. Within this research framework, the aim of this study is to investigate whether the number of followers on social media of art galleries operating in the Turkish art industry is affected by the regular content sharing of the galleries and the topics of these contents. For this purpose, the number of contents shared by art galleries in social media and their subjects were examined comparatively between the pandemic process and the pre-pandemic period through descriptive statistic method. Since Istanbul is the center of art in Turkey, the sample of the research was chosen as the galleries in Istanbul. A descriptive statistical method was used to compare art galleries between May 2018 and May 2020, when the Covid 19 Pandemic led to a rapid digital transformation. The findings show that the use of social media by art galleries varies according to the age groups of the artists they work with; content production that can meet expectations is necessary rather than content distribution frequency in art galleries which work with older artists.
\end{abstract}

Keywords: Arts Marketing, Art Galleries, Social Media, Digital Communication, Arts Management.

\section{TÜRKIYYE'DE SANAT GALERILERINIIN KARŞILAŞTIRMALI SOSYAL MEDYA ANALIZI}

\section{ÖZ}

Sanat alanında pazarlamanın amacı, sanat çalışmalarının satışı ve insanlara sanatla ilişkili bir deneyim alanı oluşturarak değerler sunmaktır. Sanat endüstrisinin bir parçası olan sanat galerileri de pazarlama çalışmalarında sosyal medyayı bu amaca yönelik yöneten kurumlar arasındadır. Bu çerçevede sanat galerileri için sosyal medya sanatçılar, koleksiyonerler ve sanat eseri satın almak veya sanatı izlemekle ilgilenen kişiler arasında köprü kuran dijital bir platformdur. Bu açıdan sanat galerilerinin bu platformu halkla iletişime yönelik nasıl etkin bir şekilde kullanabileceği bu alandaki araştırma konularından biridir. $\mathrm{Bu}$ çalışmanın amacı, Türkiye sanat endüstrisinde faaliyet gösteren sanat galerilerinin sosyal medyadaki takipçi sayılarının galerilerin içerik paylaşımlarının düzenli olmasından ve bu içeriklerinin konularından etkilenmekte olup olmadığını araştırmaktır. Bu amaçla araştırmada sosyal medyadaki sanat galerilerinin

Research Article - This article was checked by iThenticate 
paylaştıkları içerik sayıları ölçülmüş ve içerik konuları betimlenmiş; pandemi süreci ile pandemi öncesi dönem arasında karşılaştırmalı olarak betimleyici istatistik yöntemiyle analiz edilmiştir. İstanbul, Türkiye'de sanatın merkezi olduğu için, araştırmanın örneklemi İstanbul'daki galeriler olarak seçilmiştir. Covid 19 Pandemisinin hızlı bir dijital dönüşüme yol açtığı Mayıs 2018 ile Mayıs 2020 arasındaki sanat galerilerini karşılaştırmak için tanımlayıcı istatistiksel bir yöntem kullanıldı. Bulgular, sanat galerilerinin sosyal medya kullanımlarının birlikte çalıştıkları sanatçıların yaş gruplarına göre farklılık gösterdiğini; yaş grubu yüksek sanatçılarla çalışan galerilerde içerik paylaşım sıklığından ziyade içeriklerdeki konu seçiminin daha önemli olduğunu ortaya koymuştur.

Anahtar Kelimeler: Sanat Pazarlamast, Sanat Galerileri, Sosyal Medya, Dijital Iletişim, Sanat Yönetimi.

\section{INTRODUCTION}

Marketing practices have been applied as a necessity in today's art businesses. The purpose of art marketing is to sell art works and create areas of experience offering artistic value to the people. Social media has been regarded as one of the main communication channels to promote art and artists to groups who are interested in art and / or buyers of art. This situation, which is valid for all kinds of art enterprises from music to theater, from museums to visual arts centers, also supports art organizations in providing public education, advocating for arts, facilitating the understanding and accessibility of art content, and establishing close ties with the art audience.

Art galleries actively use social media as a digital platform to reach art market and public in general. The main task of the gallery manager is to bring together the collectors, artist and the art work.

Especially today, when the digital presentation of products has become important, the transfer of art as a content to virtual environments and the increasing of followers on social media by art galleries makes art accessible. In this respect, it is a research topic how art galleries can use this platform effectively. Social media offers advantages to businesses in recognizing the consumer and creating targeted behavior and attitudes by interacting with them. The behavior and attitudes of users in the market are affected by their experiences which begin from the moment the user first heard about the products or services in media environment. The experience in the digital environment is influenced by the creative content of the digital environment offered to the users. The aim of this study is to figure out how art galleries operating in the Turkish art industry benefit from content production in social media in terms of quantity and quality to increase their followers. For this purpose, the content of the social media shares of art galleries was analyzed in the research and the reactions of the users were evaluated based on this analysis. Within this research, the number of contents shared by art galleries in social media was measured together with the number of followers and subjects of contents were examined; the social media use of these art galleries comparatively between the pandemic process and the pre-pandemic period through descriptive statistic method.

A study to be conducted to art galleries to use social media in Turkey, it is necessary to take into account that they have different characteristics. These characteristics of galleries differ according to when they were founded, the communication they establish with collectors, art buyers, art audiences and artists. The galleries in Turkey can be divided into three groups. The first group consists of galleries that was opened in the 1970s. This group galleries came to be seen in Turkey when art started to be seen as an investment tool in Turkey. These galleries have mediated the introduction of the business world with art and have established communication networks within this framework. Their owners have continued the gallery works through personal communication networks. Therefore, these galleries are first generation gallery type in Turkey. Later in the acceleration of the process of commercialization of art in the 1980s, art galleries contributed to development of art market with international organizations and reaching at wider audience. These second-generation galleries are more adopted to communicate through social media with their stakeholders as they are not based only their owners' network. In the 2000s, when new technologies and communication environments started to expand, new generation gallery types were seen and the feature of these galleries carried art beyond the boundaries of a certain

Research Article - This article was checked by iThenticate

Copyright (C) The Turkish Online Journal of Design, Art and Communication 
environment and reached a wider audience. These are the third-generation galleries which has developed a marketing approach within the framework of the accessibility of this gallery type art, which uses only digital media. This study investigates how these three types of art galleries showing different characteristics in Turkey, communicate through social media. based on the assumption that institutions generally strengthen social media communication during the pandemic process, the pandemic process, which is expected to improve the digital communication of art galleries, and the pre-pandemic process were examined comparatively. Since Istanbul is the center of art and art galleries in Turkey, the sample of the research was chosen as the galleries in Istanbul. A descriptive statistical method was used to compare the social media communications of art galleries between May 2018 and May 2020, when the Covid 19 Pandemic led to a rapid digital transformation.

\section{CONTENTS AND FOLLOWERS IN SOCIAL MEDIA}

Marketing communication plays an active role in the creation and management of the brand (Aaker, 2013) that enables a product to be positioned in the mind of the consumer and to add meaning to the consumption of that product. The positive experience of the target audience with the content enables consumer to spend more time on digital platforms such as social media and web pages. This experience of the consumer includes both physical and digital environments, starting from the moment the target audience first heard about the product, and after the purchasing processes. In this context, social media functions at the point of informing their target audience about themselves and gaining a positive image in their minds. According to Varnali, when looking at experience from a marketing perspective, one point reveals the series of behaviors leading to sales, while the other is related to how the experiences accompanying this series of behaviors are remembered (Varnali, 2017). Social network sites support interaction between organizations and their publics through methods that enable people to communicate, make decisions, socialize, cooperate, learn, entertain themselves, communicate with their environment, and even shop together (Kasemsap, 2015). This has led to the re-evaluation of traditional communication practices.

Social media is rapidly expanding across and outside the enterprise, touching almost every aspect of businesses such as journalism, crisis management, politics, research, media, customer relations, public relations and marketing (Savar, 2013). There are many definitions of social media that have been made until today. Within the framework of these definitions, we can define it as any internet media that uses web 2.0 technology that allows commenting and sharing. Although Facebook, twitter and Instagram bring social media to mind, many media where photos, videos and information can be shared is classified in the social media category. The most important role of social media communication is to activate the audience.

Within the scope of marketing communication, social media is a communication channel that can be effective at every stage of their purchasing decision by enabling two-way communication due to its nature and supporting the participation of consumers in the communication process. Starting with attracting attention to the product, the effect of social media on the consumer can be used in all stages of raising interest in the product, desiring the product and taking action in purchasing the product, as well as determining the behavior of the target audience and directing the purchasing decision. For this reason, every sector uses social media in line with its goals and sees this channel as an effective means of creating a market.

Experience in social media environments emerges primarily as a result of the interaction with the contents. In this context, as stated before, the quality of the content created comes to the fore. Formats that can be considered as content in online media; website articles, news, blogs, mobile applications, infographics, images, annual reports, research articles, cases, videos, photos, and the quality of these content is determined by the target audience and the factors that affect their purchasing decisions (Kingsnorth, 2016).

Content marketing is defined as an approach where companies try to create and / or share contextually relevant content in order to create or reinforce brand messages (Baltes, 2015). While the marketing objectives of the business are decisive, it is the demographic and psychographic characteristics of the

Research Article - This article was checked by iThenticate 
consumers that determine the quality of the content and the stage of the consumer's purchasing decision. People's use of social media is motivated by individual and psychological needs (Salo, Lankinen, \& Mantymaki, 2013). The needs of consumers can change according to generations, and this can also affect social media preferences. In the report published by the global social media research group in August 2020; They stated that Facebook and Instagram are highly preferred social media platforms for $\mathrm{Y}$ and $\mathrm{Z}$ generations. According to August 2020 data in the report, it is seen that the rate of Facebook usage between the ages of 25-34 is 20\%, and the rate of Instagram usage between the ages of 25-34 is around $23 \%$. When the structure of Facebook and Instagram is examined; In 2012, it was observed that there was a large increase in the number of users with Facebook's acquisition of Instagram and as a result of this increase, businesses started to see Instagram as a platform for marketing (Kiran, Y1lmaz, \& Emre, 2019). On the other hand, although social media content is thought to be managed by users, social media applications have purposes determined by businesses such as marketing and information management (Kane, Alavi, Labianca, \& Borgatti, 2014).

The production of content that will attract the attention of users increases the followers' numbers of organizations. According to Chen \& Lei $(2021,177)$, "Followers perceive benefits for practical content, which can increase their attention to the official account". By attracting the users through contents, the engagement process begins on social media. Customer engagement is a concept which is categorized by Dessart et al. (2015) as affective engagement (refers to enthusiasm and enjoyment), cognitive engagement (refers to atttention and absorpotion), and behavioral engagement (refers to learning, sharing and endorsing). Becoming a follower of an official account on social media is an important preliminary step as the first step towards getting these engagement levels started. Continuing to follow can be seen as a positive user behavior towards engagement.

\section{ACCESIBILITY OF ART THROUGH SOCIAL MEDIA CONTENTS}

Marketing is one of the knowledge and skills that an art manager should have in 21st century (Byrens, 2008). This situation has made art organizations a part of the creative industry sector where creativity and art are transformed into economic value. Unlike in the past, this industry has enabled art to get out of its closed introverted environment and get rid of its hierarchical structure and even to stand against the elitist approach. Marketing ensures that elements such as art works, exhibitions and events, which are the products of the galleries, are delivered to the target audience within a certain positioning framework. Positioning is the definition of what an organization offers to the market, for whom, under what conditions, and in competition with whom. In this respect, the aim of arts marketing is not limited with increasing the selling of art. There are four areas in which art marketing produces solutions: encouraging participation, audience development, membership development, and fundraising (Kotler, 1980). These areas contribute to the experience of an artistic experience and to reach the target audience in terms of quantity and quality. In this context, art organizations benefit from communication methods in line with their goals. In this way, communication makes art accessible by spreading values related to art (Botti, 2000, 23-24). Thus, arts marketing uses marketing to promote participation in the arts by making the arts accessible. While art organizations develop audience communities, they can create an online space where the audience will be around the organization and the arts in the web environment, as they do in the physical space (Larsen, 2014).

Today, art organizations use social media as a communication tool that enriches the artistic experience. This experience of the audience starts not in the art space, but by watching, listening and commenting on digital content such as social media before coming to the art institution, which provides a rationale for experiencing art spaces (Kolb, 2014). In this context, social media has been a part of this process. Audience can produce content on today's social media platforms is almost equal to the artist and the only hierarchy is between the likes and dislikes of the consumer (Kolb, 2014). As one of the organizations that have taken their place in the creative industry, art galleries are bringing together the buyer of the art work and the art work or artist, and legitimizing the artists they work with in the art environment and art circles (Jyrämä \& Äyväri, 2010).

Research Article - This article was checked by iThenticate 
Experience, which is an important element of today's marketing strategies, includes every environment where the art organization communicates with the audience through art, apart from directly confronting art. At this point, psychographic segmentation showing motivations, attitudes and behaviors is important. In fact, it is ideal to design marketing communication applications by segmenting them demographic, psychographic and geographic. Considering that today's marketing approach focuses on the consumer and his / her experience; art marketing requires understanding the relationships of individuals with art and their motivation to be a viewer or participant of art. These motivations, which are defined as follows: (1) functional / cultural benefits to enrich education, knowledge, culture; (2) the symbolic benefits of the cultural meaning of art to represent the identity and personality of individuals; (3) benefits that enable social contact through being an art audience; (4) experience in individuals' inner worlds through art (Botti, 2000). In today's consumer-oriented approach, these motivations should be taken into account in order for art to reach and interact with the audience. For example, the fact that there are those who think that sharing this experience in an online community is as important as experiencing art among today's individuals (Kolb, 2014) explains the reason why art organizations reach individuals through social media. For this reason, art organizations communicate directly with the audience by raising questions on social media sites such as Facebook and making discussion invitations (Larsen, 2014, s. 146). For this reason, every motivation that directs individuals to art is taken into consideration in terms of establishing a connection with the audience of art organizations.

\section{RESEARCH}

The aim of this study is to understand the development of social media communication practices in Turkey. For this purpose, social media contents of art galleries were measured comparatively between the pandemic process and the pre-pandemic period. The data were analyzed through descriptive statistic method. Since Istanbul is the center of art and art galleries in Turkey, the sample of the research was chosen as the galleries in Istanbul. A descriptive statistical method was used to compare the social media communications of art galleries between May 2018 and May 2020, when the Covid 19 Pandemic led to a rapid digital transformation. In this context, on the dates considered the content categories of art galleries' posts were defined as well as the numbers of posts and followers. Monthly statistical data was taken from Facebook, twitter and Instagram which are the commonly used by the galleries addressed in the study. Additionally, some galleries were examined more than a month addressed in the study to evaluate the result in more detail.

The art galleries considered as samples are twelve art galleries examined in three groups that differ in terms of target audience, stakeholder, market and organizational. Galleries taken in the first group are the first generation of galleries representing the gallery business in the period in which first emerged in Turkey. These are organizations that galleries have opened in Turkey led to the development of art collecting in the 1970s and 1980s. The feature of these galleries is that the owners improve the communication of the gallery within the framework of the interpersonal communication they establish with the business environment (Interview with the manager of Gallery Baraz, Yahşi Baraz, 2018; Interview with Haldun Dostoğlu, the manager of Galeri Nev Istanbul, 2018). The founders of this gallery in the 1960s, the world of business is given the direction of art relationships have led to the formation of the art market in Turkey. Of these, Galeri Baraz (1975) is one of the first examples that survived until today. Afterwards, galleries that were part of this process were opened in the 1980s and 1990s. The galleries that are considered as examples in the study are these art galleries that were opened in this period between 1970-1990 and continued their existence. The other galleries were Gallery Baraz (1975), Gallery Nev (1984), Gallery Nev İstanbul, Gallery Artist (1986) and Gallery Apel (1998). Of these, Galeri Nev is located in Ankara, unlike the sample discussed in this study. The reason for this is that after the gallery was first opened in Ankara, the owners parted ways and added Istanbul to its name and continued its activities in Istanbul. Since the name of Galeri Nev will cover both organizations, the organization in Ankara was also included in the scope of the study. One of the most important reasons why these art galleries are considered as a separate group is the age group of the artists they work with. The characteristic of this group of galleries is that the birth dates of most of the artists are between 19001950 and they represent the $\mathrm{X}$ generation (figure 1).

Research Article - This article was checked by iThenticate 


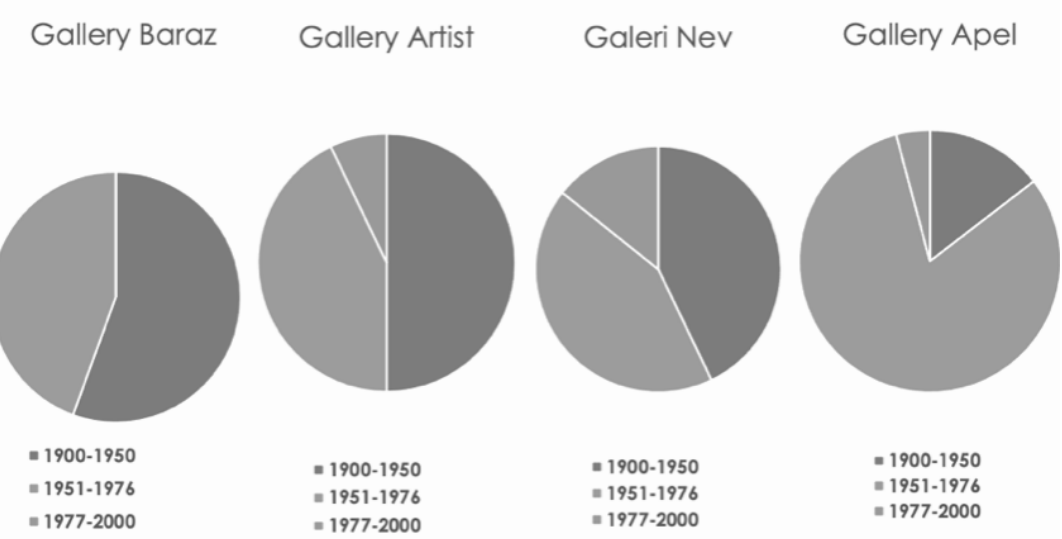

Figure 1: Birth Dates of the First Group Galleries' Artists

The second group of galleries, taken as an example in the study, are galleries was opened in the period when new communication technologies started to develop after 2000. These galleries were determined as Dirimart (2002), Galeri Eksen (2011), Mixer (2012) and Krank Art Gallery (2016). Among the artists with whom the galleries in this group work together, there are artists representing the $\mathrm{Y}$ and $\mathrm{Z}$ generations, whose birth dates are higher than the first group galleries, as well as those of the $\mathrm{Y}$ and $\mathrm{Z}$ generations (figure 2)

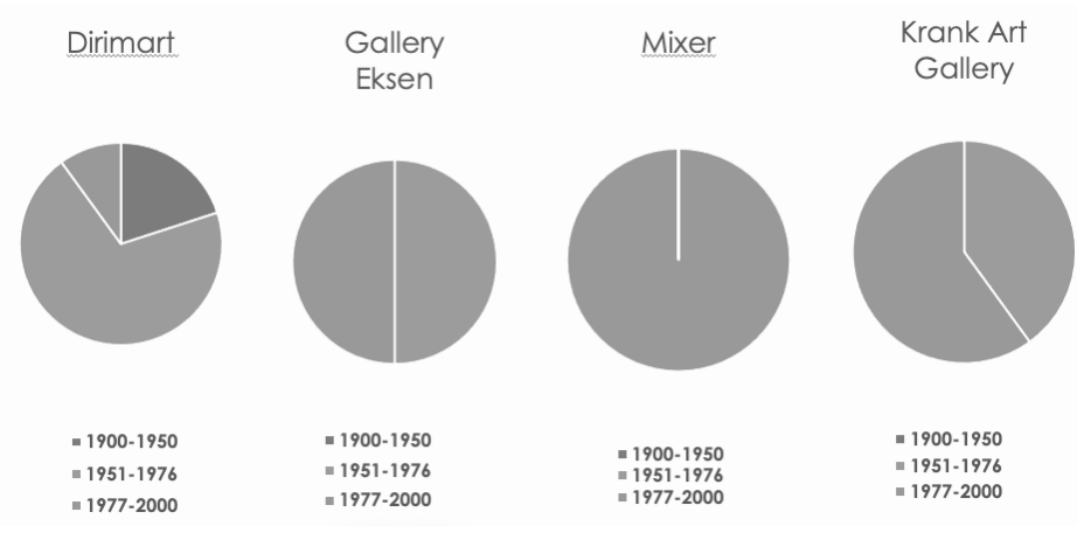

Figure 2: Birth Dates of The Second Group Galleries’ Artists

The third group of art galleries taken as an example in the study are digital galleries that have primarily created themselves in the digital environment. These third-generation galleries are Gallery Lebriz / Lebriz.com (1980/2000), Sanat gezgini.com (2017), Artnivo (2014) and Art50.net (2014). In the third group of galleries, representation of the $\mathrm{X}$ generation artists is less common (figure 3 ).

Research Article - This article was checked by iThenticate 


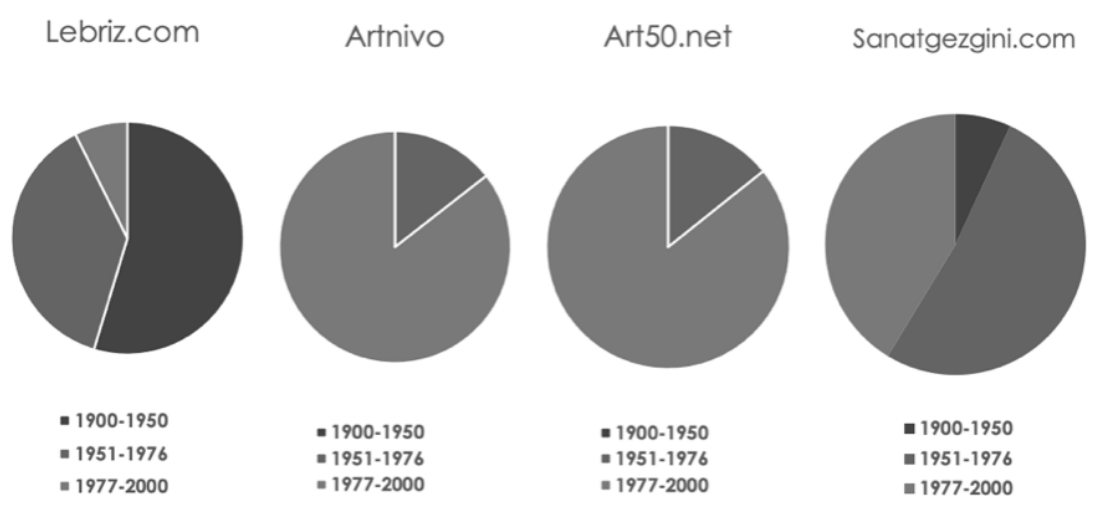

Figure 3: Birth Dates of the Third Group Galleries’ Artists

\begin{abstract}
ANALYSIS AND COMMENTS
Art galleries mostly use Facebook, twitter and Instagram as communication channels together. However, the research shows that Instagram is an option that is considered by all types of galleries. Considering the number of followers of the art galleries in general subject to this study in May 2018, followers of the first group galleries (Gallery Baraz, Gallery Artist, Gallery Nev, Gallery Nev Istanbul and Gallery Apel) on Facebook were lower in number than second (Dirimart, Gallery Eksen, Mixer) and third group galleries (Lebriz.com, Artnivo, Art50.net, Krank Art Gallery and Sanat Gezgini.com) (table 1). These first group of galleries were followed by more people on Instagram in 2018 and this situation did not change in 2020. In fact, all galleries except Gallery Artist have increased their followers on Instagram in 2020 (table 2).
\end{abstract}

Table 1. Number of Followers of Art Galleries on Facebook, Instagram and Twitter in May 2018

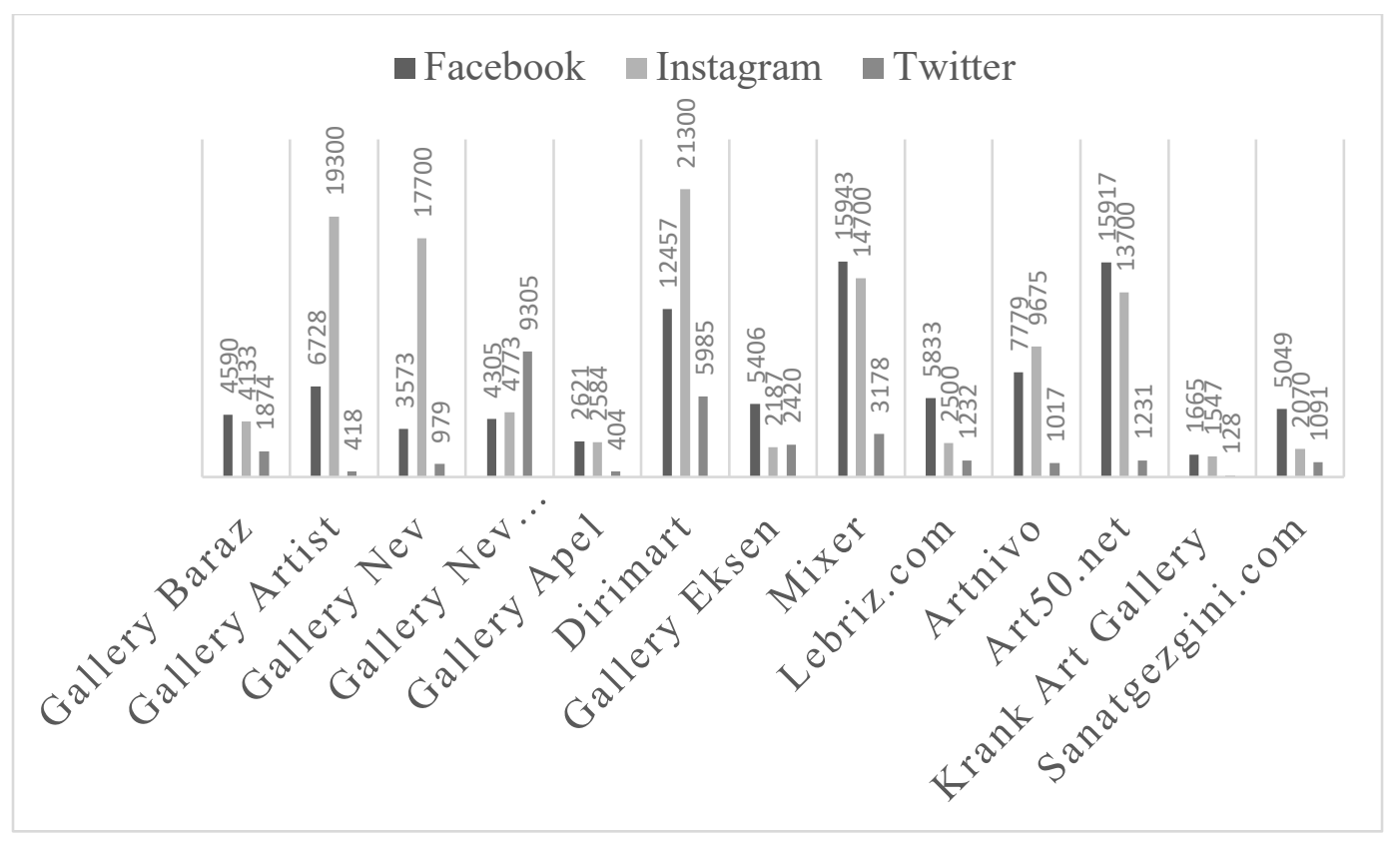

Submit Date: 25.01.2022, Acceptance Date: 15.02.2022, DOI NO: 10.7456/11202100/009

Research Article - This article was checked by iThenticate

Copyright (C) The Turkish Online Journal of Design, Art and Communication 
Table 2. The Number of Followers of Art Galleries on Facebook, Instagram and Twitter for May 2020

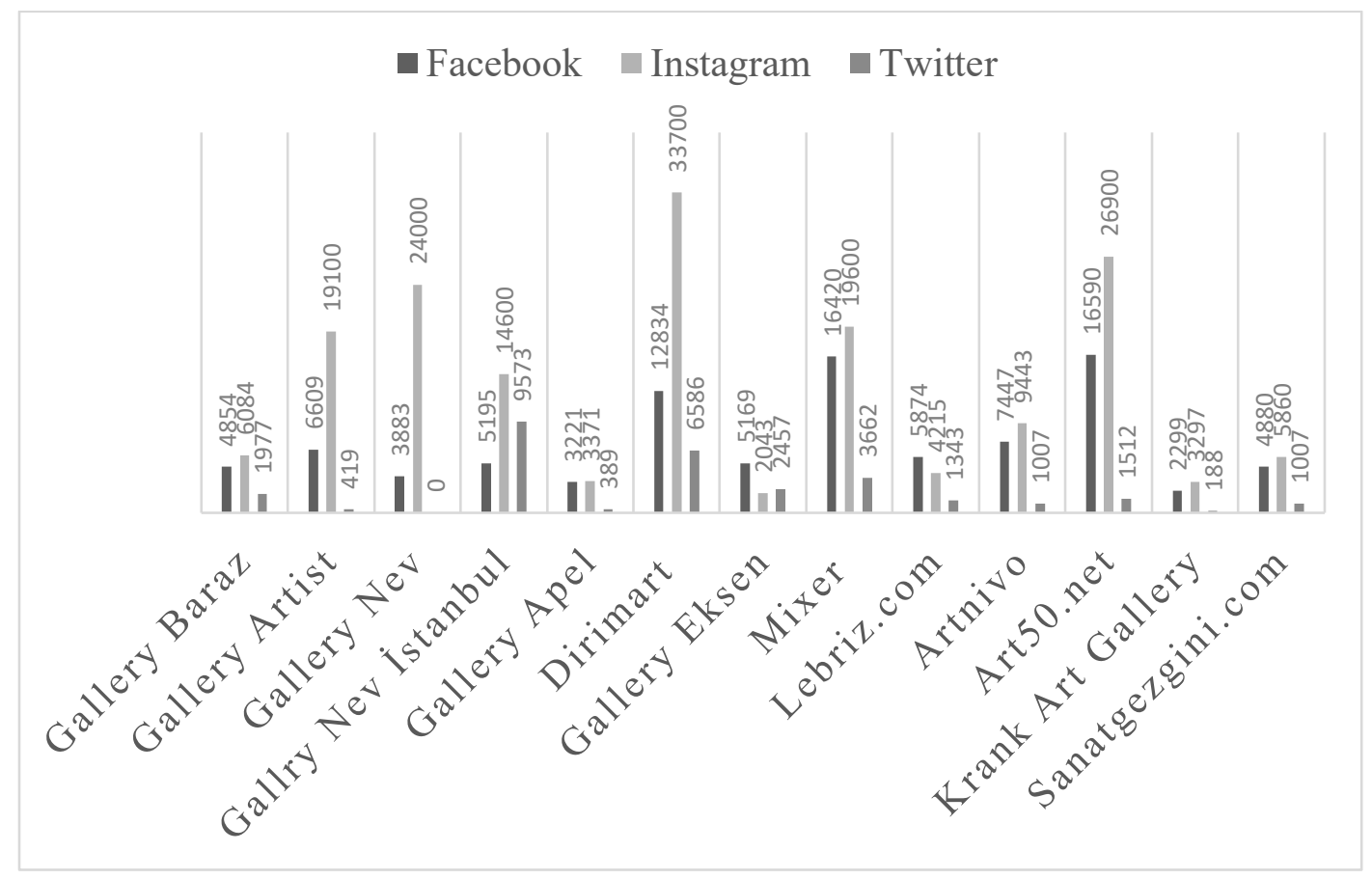

Instagram followers of the first group galleries were increased except Gallery Artist. This increase was not always directly proportional with the numbers of posts but It was determined that only Gallery Nev İstanbul increased its followers by $205 \%$ in parallel to the increase in its posts by $15,3 \%$ (table 3 and 5). On the other hand, Gallery Baraz which reduced Instagram posts by $83.3 \%$ on Instagram increased the number of followers by 47,2\% (table 4 and 5). This situation seen in also in the case of Gallery Nev and Gallery Apel, in which the number of followers increased despite the decrease in the number of posts, gives the impression that after the pandemic, it was attempted to $341 \mathrm{ccess}$ the galleries in the digital environment, which could not be accessed in the physical environment. However, this increase can be related with the galleries' posts before the May 2020 pandemic. For example, when we examined it in the case of Gallery Baraz, it was figured out that the gallery was sharing more actively on Instagram until February 2020 and it has stopped sharing as of March, when the pandemic appeared. Therefore, it is possible that the number of Gallery Baraz followers increased before May 2020. 
Table 3. Comparison of the First Group Art Galleries' Facebook, Instagram and Twitter Posts on May 2018 May and May 2020

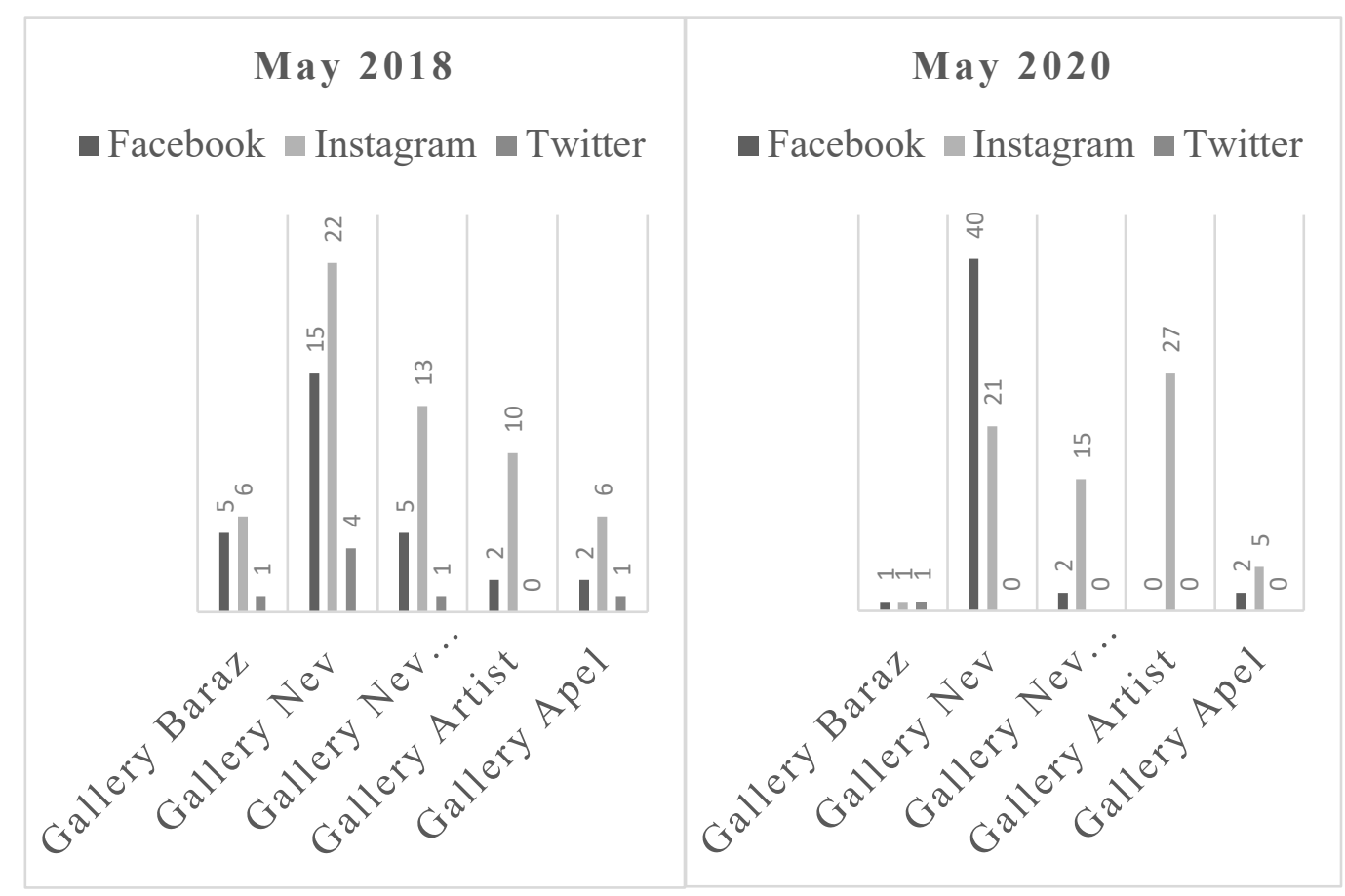

Another example of this kind of disproportionate findings, Galeri Artist which increased the number of contents on Instagram by $170 \%$, the number of followers has decreased by $1 \%$ (table 4 and 5 ). In order to understand the reason for this situation, the number of Instagram posts of Gallery Artist in the past two years was examined. Accordingly, the gallery shared 93 posts in 2018 and 82 in 2019. Therefore, there is a possibility that the number of followers has decreased over time due to the fact that Gallery Artist has reduced the number of contents even more. The in-depth analysis of this situation on Instagram shows that first group of galleries have more followers when they shared more Instagram posts.

The analysis of the first group of galleries' Facebook posts on May 2020 showed that only Gallery Nev increased posts. However, the increase of Gallery Nev's posts in high rate did not cause the gallery to increase the number of followers. While the increase of Gallery Nev posts by $166,6 \%$, the followers increased only by $6,9 \%$ (table 4 and 5 ). In addition to this, all the galleries in this second group increased their followers even if they reduced their posts in Facebook such as Gallery Nev İstanbul and Gallery Artist (table 4 and 5). Of these Galleries, it was figured out that Galeri Nev Istanbul continued to share content, even if a little, after the pandemic and Galeri Artist, has provided this increase due to his shares from previous periods.

Research Article - This article was checked by iThenticate 
Table 4. Comparison of Facebook, Instagram and Twitter Followers of the First Group Art Galleries on May 2018 and May 2020

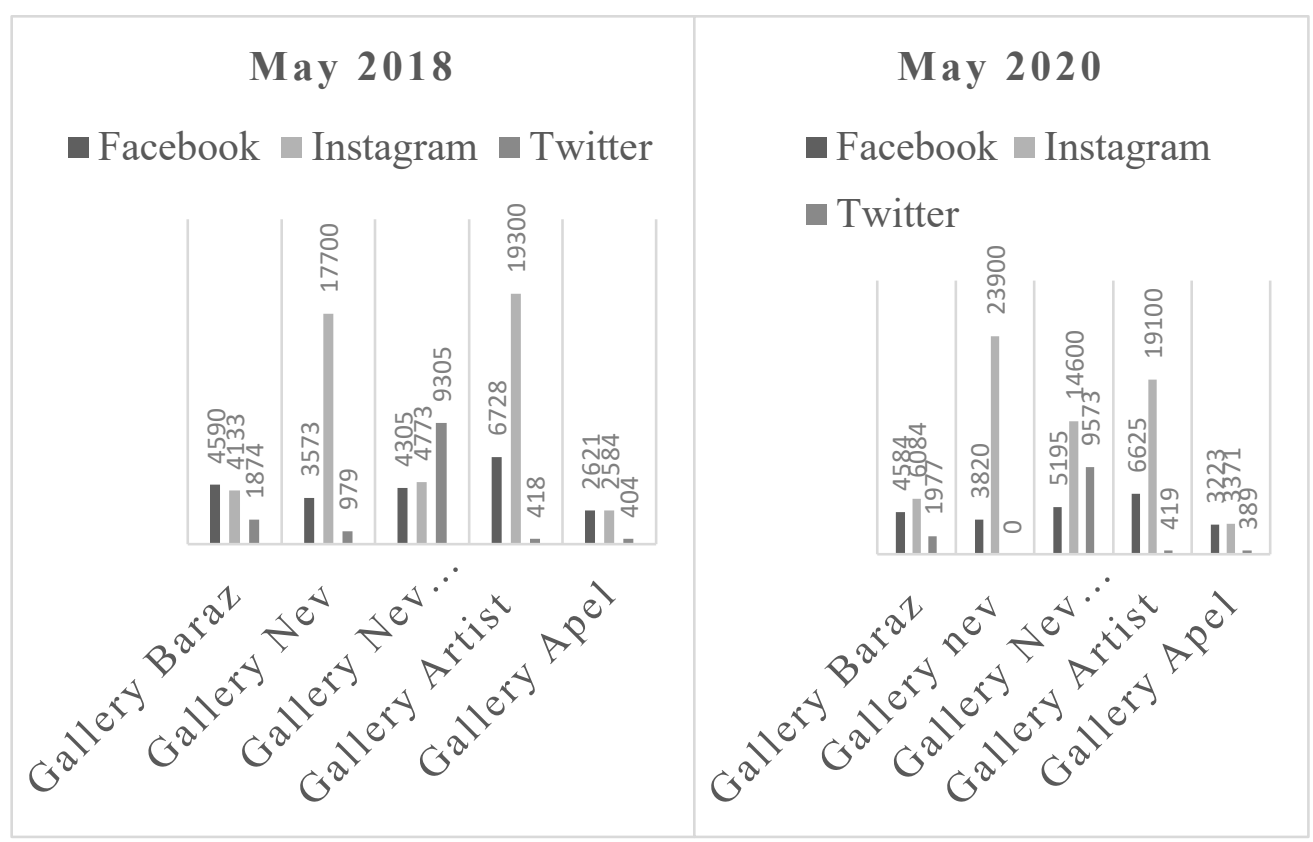

The analysis of the first group of galleries' Facebook posts showed that twitter posts were remained same or less. Inspire of these numbers (table 5) followers of the first group galleries on twitter were increased except Gallery Artist.

Table 5: Proportional Comparison of the First Group Art Galleries Facebook, Instagram and Twitter May 2018- May 2020 May Posts-Audience Numbers

\begin{tabular}{|c|c|c|c|c|c|c|}
\hline & \multicolumn{2}{|c|}{ Facebook } & \multicolumn{2}{|c|}{ Instagram } & \multicolumn{2}{|c|}{ Twitter } \\
\hline & Posts & Followers & Posts & Followers & Posts & Followers \\
\hline Gallery Baraz & $80 \%$ & $1 \%$ & $83,3 \%$ & $47,2 \%$ & No change & $5,4 \%$ \\
\hline Gallery Nev & $166,6 \%$ & $6,9 \%$ & $4,5 \%$ & $40,5 \%$ & $100 \%$ & $100 \%$ \\
\hline $\begin{array}{l}\text { Gallery Nev } \\
\text { İstanbul }\end{array}$ & $60 \%$ & $20,6 \%$ & $15,3 \%$ & $205 \%$ & $100 \%$ & $2,8 \%$ \\
\hline Gallery Artist & $100 \%$ & $5,5 \%$ & $170 \%$ & $1 \%$ & No change & $1 \%$ \\
\hline Gallery Apel & No change & $30 \%$ & $16,6 \%$ & $30,4 \%$ & $100 \%$ & $4 \%$ \\
\hline
\end{tabular}

According to the content classification of social media posts for the first group art galleries, the categories of contents determined as presentation of the artist / exhibition / art work; promotion of other activities of the gallery; sales development for the gallery/ exhibition visit; the story of the owner of the gallery/ the story of the artist / collector; the news about the gallery in the media; the promotion of the gallery initiatives; the contents directed to the web; news about the art market and the promotion of consultancy services. When the content of first group of galleries' posts are examined one by one, it is seen that the galleries that regularly share posts in same content categories or diversify its content categories do not lose followers even if they reduce their posts in number. For example, it is seen that 
Galeri Nev Istanbul, whose number of followers has increased despite the decrease in the number of posts on Facebook, does not change its content categories, but concentrates on content that informs its target audience about past and future events. Similarly, Gallery Apel, which diversifies the content categories in terms of providing information, has become a gallery that increases the number of followers. In addition to increasing the number of contents on Instagram by $65 \%$, Gallery Apel added two new types to its content categories. These types are the introduction of gallery activities, informative content that leads to the web. Therefore, these galleries, which cannot be reached in the physical environment during the pandemic process, produce content that can communicate with their target audience, although they are few in number, it may be aimed at maintaining communication with the target audience. In this case, the quality of the content becomes the primary criterion in terms of maintaining communication with the follower. On the other hand, Galeri Baraz, whose number of followers has increased despite the decrease in the number of contents on Instagram, has also decreased his previous posts. The contents that Gallery Baraz has interrupted sharing posts in categories of artist / exhibition / art work promotion; the sales development for the gallery; promotion of other activities of the gallery. Therefore, it is clear that Galeri Baraz could not meet the expectations of the audience in the digital environment on May 2020.

When the contents of the second group of galleries in May 2018 and May 2020 are analyzed comparatively, it was seen that they mostly attach more importance to the use of Instagram and twitter than Facebook in 2020. Dirimart reduced Facebook usage by 55,5\% and Mixer by $60 \%$ in May 2020 (table 6 and 8). Moreover, Gallery Eksen and Krank Art Gallery did not share any posts in May 2020 on Facebook. In parallel to decrease their Facebook posts, most of these galleries reduced the number of contents on Instagram. Dirimart reduced Instagram posts by $13,7 \%$, Mixer by $43,7 \%$, and Gallery Eksen increased by $100 \%$. On the other hand, a striking result is that the use of twitter has increased by $95 \%$ by Dirimart, and $63 \%$ by Krank art gallery (table 6 and 8 ). This shows that the second group galleries tend to use twitter in a way that is not seen in the first group galleries. In addition to this, it was determined that followers of the second group galleries were increeased directly proportional to the increase in twitter posts (table 7 and 8).

In the second group of galleries, as in the first group galleries, it has been observed that the number of followers can increase in the galleries that reduce the number of posts. On Facebook, Dirimart which reduced the number of posts by $56 \%$ increased its followers by $3 \%$; Mixer which decreased posts by $40 \%$ increased its followers by 3\%. Moreover, Gallery Eksen and Krank Art Gallery which decreased their posts by $100 \%$ (they didn't share any post on May 2020) increased their followers (tables 7 and table 8). A similar situation is observed on Instagram and Facebook. The figures shows that the galleries increased their followers' numbers both on Instagram and Facebook, in spite of the decrease in their posts. On Instagram, Dirimart which decreased the number of posts by $14 \%$, was increased its followers by $57 \%$; Mixer which reduced the number of posts by $44 \%$ was increased its followers by $25 \%$ (table 8 ). On twitter, the number of Galeri Eksen followers, which does not share any posts, was increased by $2 \%$, and number of Mixer followers, which reduced the number of posts by $84 \%$, was increased by $14 \%$ (table 8). It is possible that the increase in the number of followers of these galleries is due to the posts made in previous years. Additionally, looking at whether this situation is related to the changes in content categories, it is seen that Dirimart has enriched its content categories by starting to share content that introduces gallery initiatives and gives information about the art / art market that directs followers to its web site. Similarly, unlike 2018, Mixer has enriched the content categories in its social media posts with the content that it conducts sales development activities for gallery / exhibition visits, introduces gallery initiatives and directs it to the web. The same is true for the Krank Art Gallery, which increased the number of its followers despite the decrease in the number of its posts. Krank Art gallery has become a gallery that promotes gallery initiatives and enriches its content categories by starting to share content that provides information about the art / art market, differently from 2018.

Research Article - This article was checked by iThenticate 
Table 6. Comparison of the Second Group Art Galleries' Facebook, Instagram and Twitter Posts on May 2018 May and May 2020

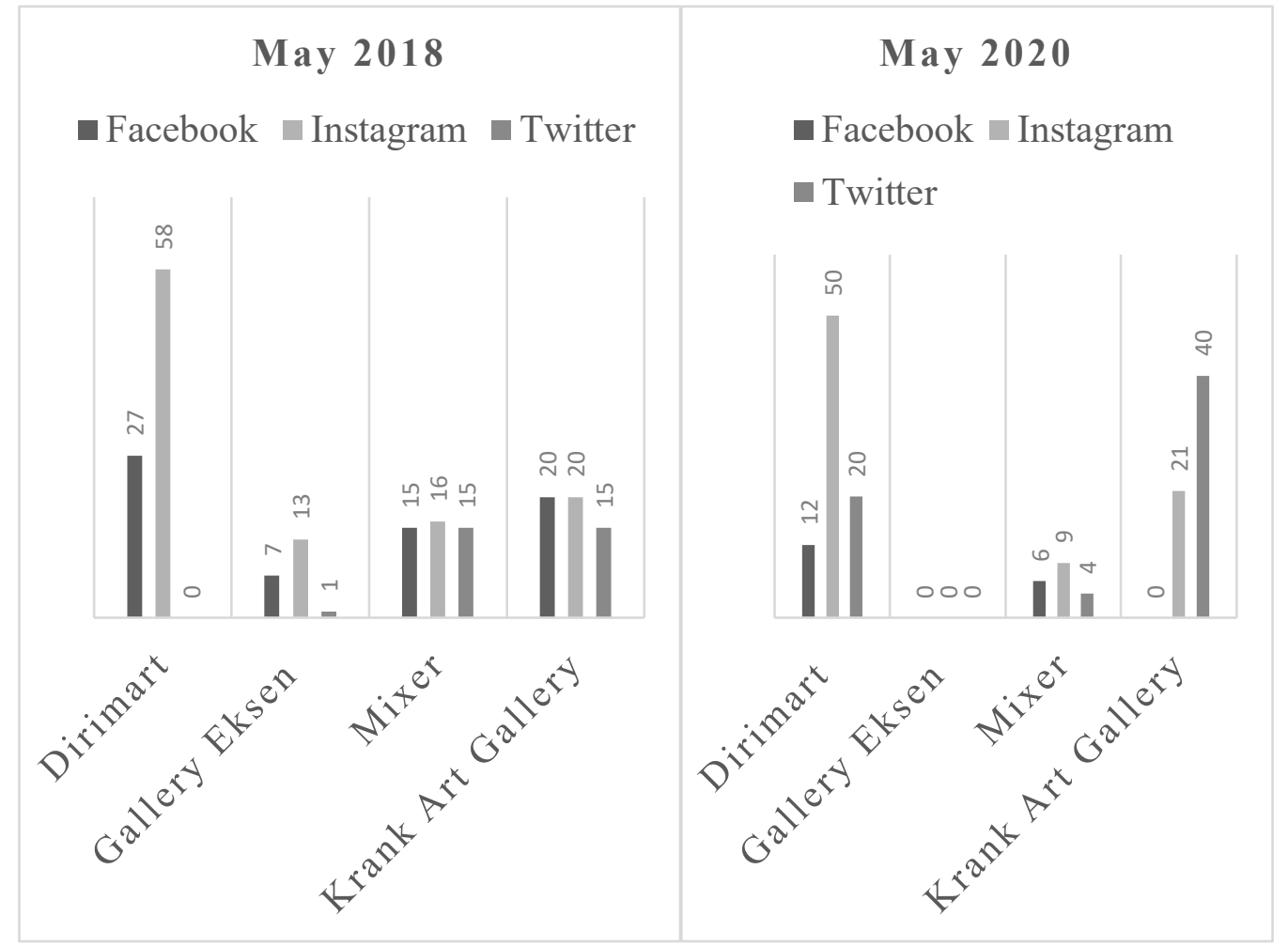

Table 7. Comparison of Facebook, Instagram and Twitter Followers of the Second Group Art Galleries on May 2018 and May 2020

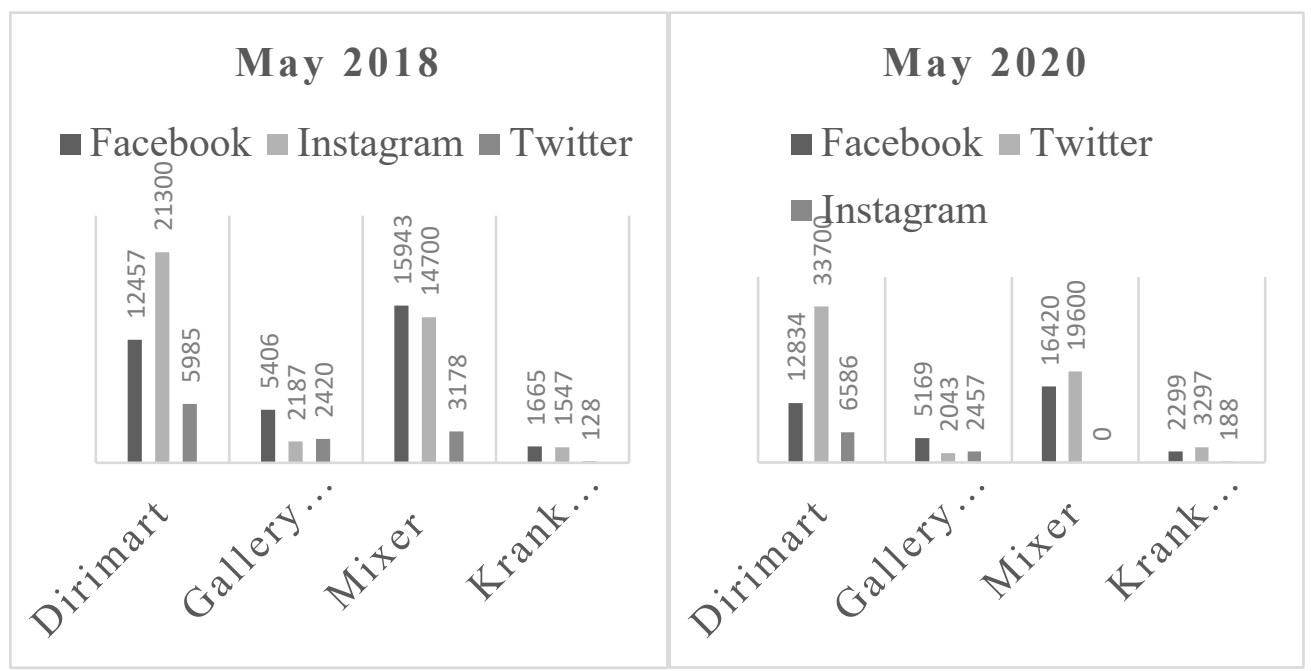


Table 8. Proportional Comparison of the Second Group Art Galleries Facebook, Instagram and Twitter May 2018- May 2020 May Posts and Audience Numbers

\begin{tabular}{|c|c|c|c|c|c|c|}
\hline & \multicolumn{2}{|c|}{ Facebook } & \multicolumn{2}{|c|}{ Instagram } & \multicolumn{2}{|c|}{ Twitter } \\
\hline & Posts & Followers & Posts & Followers & Posts & Followers \\
\hline Dirimart & $55,5 \%$ & $3 \%$ & $13,7 \%$ & $58.2 \%$ & 195\% & $11 \%$ \\
\hline Gallery Eksen & $100 \%$ & $4,3 \%$ & $100 \%$ & $6,5 \%$ & $100 \%$ & $1,5 \%$ \\
\hline Mixer & $60 \%$ & $3 \%$ & $43,7 \%$ & $33,3 \%$ & $73,3 \%$ & $100 \%$ \\
\hline Krank Art Gallery & $100 \%$ & $38 \%$ & $5 \%$ & $113 \%$ & $63 \%$ & $166 \%$ \\
\hline
\end{tabular}

In the third group galleries, it was seen that Facebook was prioritized by some galleries at the same rate as well as twitter and Instagram. The use of twitter, which stands out in the second group of galleries, is not common in the third group galleries. It was determined as a remarkable data that only sanatgezgini.com has increased the number of posts on Twitter by $3900 \%$ which a very high rate (Table 9). However, the increase in followers of sanatgezgini.com on twitter is not that high. Although the number of posts of Lebriz.com remained the same as in 2018, it is notable as a gallery that has increased its follower count. (Table 10-11).

Compared to May 2018, it was determined that Facebook usage did not decrease significantly. The highest decrease was $11 \%$ in the number of posts of lebriz.com (table 9 and 11). On the contrary, Instagram usage of Lebriz.com in a significant rate by $94 \%$ (table 10 and 11).

Table 9. Comparison of the Third Group Art Galleries' Facebook, Instagram and Twitter Posts on May 2018 May and May 2020

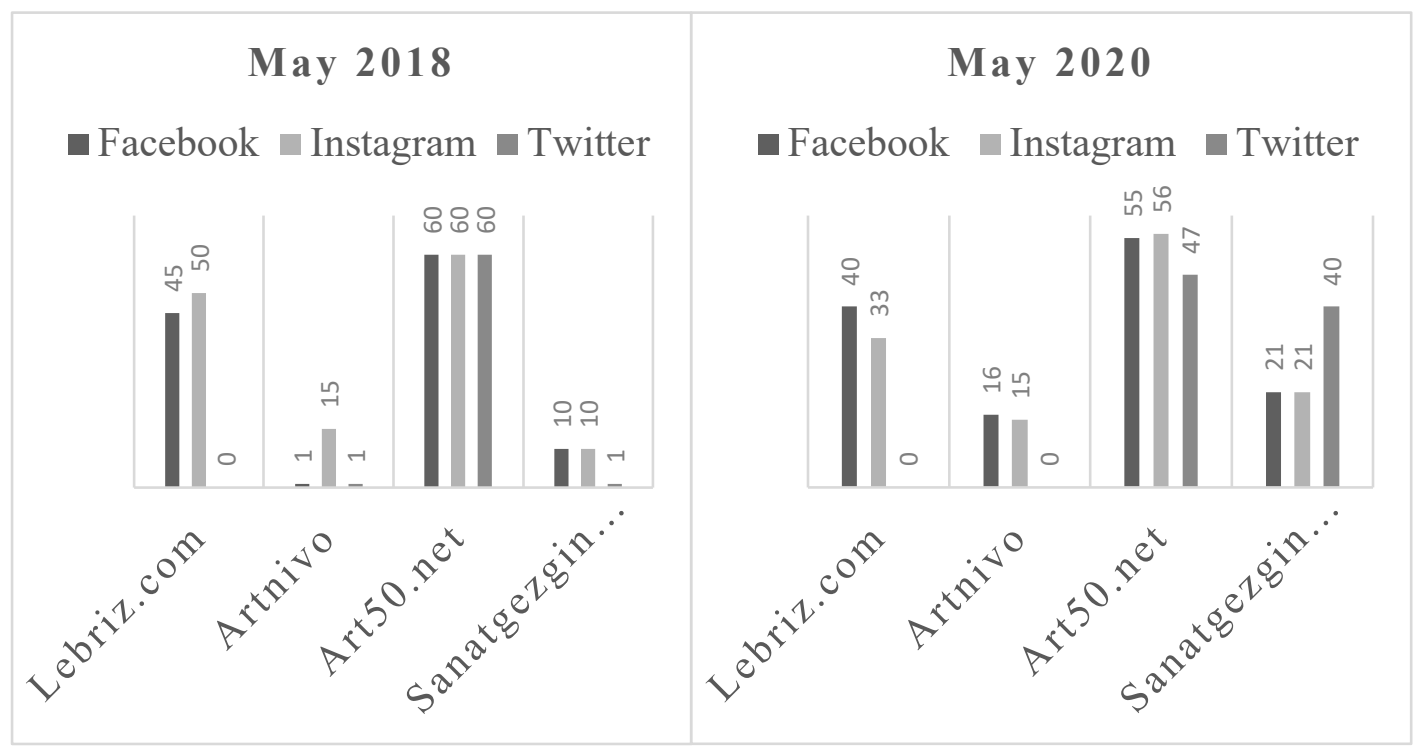

The categories determined when the contents of the third group galleries' shares on social media are analyzed; artist / exhibition / art work promotion; promotion of other activities of the gallery; sales development for the gallery / exhibition visit; the story of the owner of the gallery; the story of the artist / collector; the introduction of the gallery initiatives; the content that leads to the web; news about the art / art market, the promotion of consultancy services. The common feature of the galleries, which increase the number of followers despite of the decrease in the number of posts on social media, is that they promote gallery activities, give news about the art / art market; introduce artist exhibitions; artworks

Research Article - This article was checked by iThenticate

Copyright (C) The Turkish Online Journal of Design, Art and Communication 
and share of contents that leads to the web. Some of these content categories such as promotion of gallery activities; news about the art / art market were not dedected in the galleries, whose number of followers have decreased despite of the increase in the number of posts. This situation points out that the followers of the third group galleries are interested in the activities of the gallery and news about art and therefore they benefit from social media.

In the third group of galleries, unlike other gallery groups, the increase in the content is generally directly proportional to the increase in the number of followers. Only exceptional data was taken from Art50.net. Insipte of the 53\% increase in Instagram posts of Art50.net, the gallery lost followers by 65\% (table 11).

Table 10. Comparison of the Third Group Art Galleries' Facebook, Instagram and Twitter 2018 May 2020 May Followers

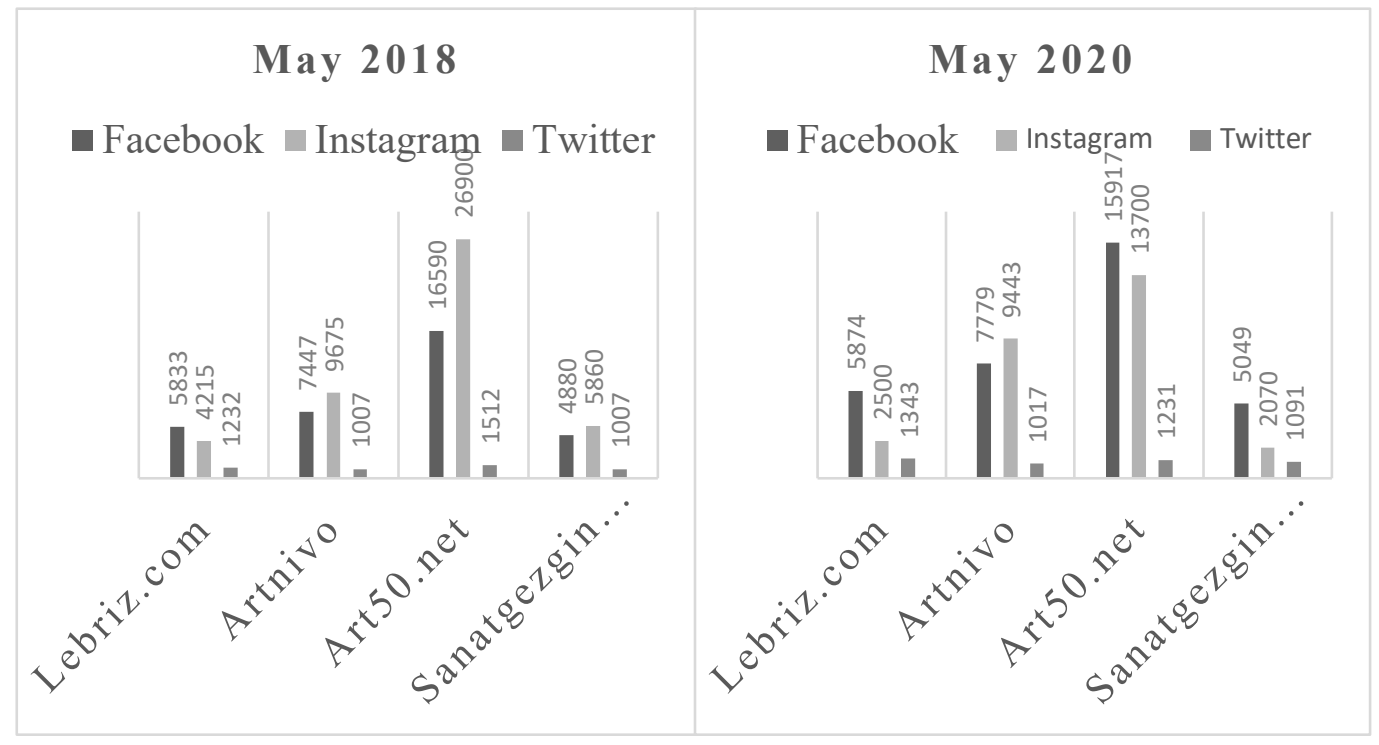

Table 11. Proportional Comparison of the Third Group Art Galleries' Facebook, Instagram and Twitter Posts and Audience Numbers for 2018 May and May 2020

\begin{tabular}{|c|c|c|c|c|c|c|}
\hline & \multicolumn{2}{|c|}{ Facebook } & \multicolumn{2}{|c|}{ Instagram } & \multicolumn{2}{|c|}{ Twitter } \\
\hline & Posts & Followers & Posts & Followers & Posts & Followers \\
\hline Lebriz.com & $11 \%$ & $1 \%$ & $94 \%$ & $40 \%$ & No change & $9 \%$ \\
\hline Artnivo & $95 \%$ & $4,4 \%$ & No change & $2 \%$ & $100 \%$ & $1 \%$ \\
\hline Art50.net & $8,3 \%$ & $4 \%$ & $6,6 \%$ & $50 \%$ & $21,6 \%$ & $8,5 \%$ \\
\hline Sanatgezgini.com & $53 \%$ & $4 \%$ & $53 \%$ & $65 \%$ & $3900 \%$ & \\
\hline
\end{tabular}

\section{RESULT}

Art galleries care about the use of social media both in 2018 and 2020. The experience that the galleries offer to the users can be listed as promoting gallery services, making use of their services, selling, providing public education, advocating for art, facilitating the comprehensibility and accessibility of art contents. Galleries have tended towards the goal of creating an accessible art platform for the public in general.

It was observed that some social media platforms have been given priority of using. Most of the galleries have started to prefer Instagram instead of content sharing on Facebook which is in parallel to the tendency in the world. It is seen that even galleries that prefer face-to-face communication and interpersonal communication to mass communication attach more importance to communication via 
Instagram. Even though the number of content increases, the non-maintenance of the content in the category that the audience is used to causes a decrease in the number of followers.

Generally, it is known that the number of followers increases if businesses regularly share content on social media. This study revealed that this situation is not valid for art followers on social media. Although, according to the results of the research, it was seen that the lack of sharing or increase in posts caused the loss of followers, it was seen that the content category was an effective factor on the basis of the disproportionate relationship between the number of followers and the number of contents.

On the other hand, it has been figured out that this is not the case for the followers of the galleries that use digital as their primary communication medium. The followers of galleries that maintain their presence in the digital environment care about regular content production, otherwise the gallery cannot meet their expectations. The common feature of galleries that increase and develop social media content and increase the number of followers is to increase website traffic, share content for sales development, share art news and promote gallery activities. Young artists are promoted more in social media in terms of gallery characteristics.

When the galleries which lost their followers inspire of increase their posts in numbers were considered as a case, it can be said that the galleries that those galleries decrease their posts in number (usually these are traditional galleries) are the ones whose number of followers have increased is due to the active communication activities in the physical environment before pandemic. This situation, which is more common in the first and second group galleries, can be explained as the audience's turning to social media in order to follow this gallery as a result of physical experiences such as their previous exhibition visit. The disproportionate increase in the number of followers with the number of shares is not a common situation in the new generation third group galleries. Since those are the galleries which were born in the digital environment and their public may be among younger population like the artists they work, it may be possible to say their followers directly reacts positively or negatively to the change in content.

It has been observed that the galleries that share informative content, which could not do activities in the physical environment during the pandemic period when the galleries were closed or started to organize activities in different forms, could continue to communicate with their followers. Therefore, it can be said that the content production of art galleries should not depend on the activities in physical spaces. When the contents are examined, it is seen that establishing two-way communication with the audience directly on social media is not a main purpose for the galleries.

\section{REFERENCES}

Aaker, D. (2013). Creating strong brands. Istanbul: Mediacat Books.

Baltes, L. P. (2015). Content marketing - the fundamental tool of digital marketing. Bulletin of the Transilvania University of Brasov Series V: Economic Series, 8(57), 112-117.

Botti, S. (2000). What role for marketing in the arts? an analysis of arts consumption and artistic value. International Journal of Arts Management, 2(3), 14-27.

Byrens, W. (2008). Management and the arts . New York: Routledge.

Chen, Y., \& Lei, W. S. C. (2021). Behavioral study of social media followers of a music event: a case study of a Chinese music festival. Journal of Hospitality and Tourism Insights, 4 (2), 163-182.

Dessart, L., Veloutsou, C. \& Morgan-Thomas, A. (2015), "Consumer engagement in online brand communities: a social media perspective", Journal of Product \& Brand Management, Vol. 24 (1), 2842.

Jyrämä, A., \& Äyväri, A. (2010). Marketing contemporary visual art. Marketing Intelligence \& Planning, 8(6), 723-735.

Research Article - This article was checked by iThenticate 
Kane, G. C., Alavi, M., Labianca, G., \& Borgatti, S. P. (2014). What's different about social media networks? A Framework and research agenda. MIS Quarterly, 38(1), 275-304.

Kasemsap, K. (2015). The role of social media in international advertising . N. Ö. Taşkıran, \& R. Y1lmaz içinde, Handbook of research on effective advertising strategies in the social media age (s. 171-196). Pennsylvania: IGI Global.

Kingsnorth, S. (2016). Digital marketing strategy. Philedelphia: Kogan Page.

Kiran, S., Y1lmaz, C., \& Emre, İ. E. (2019). The effect of influencers in Instagram on followers. International Journal of Management Information Systems and Computer Science, 3(2), 100-111.

Kolb, B. (2014). Using social media to enhance the customer attendance experience. D. O'Reilly, R. Rentschler, \& T. A. Kirchner içinde, The Routledge companion to arts marketing (s. 161-170). Oxon: Routledge.

Kotler, P. (1980). Foreword. M. P. Mokwa içinde, Marketing the arts (s. xi-xiii). Westport: Greenwood Publishing.

Larsen, G. (2014). Consuming the arts. D. O'Reilly, R. Rentschler, \& T. A. Kirchner içinde, The Routledge companion to arts marketing (s. 183-194). Oxon: Routledge.

Salo, J., Lankinen, M., \& Mantymaki, M. (2013). The use of social media for artist marketing: music industry perspectives and consumer motivations. International Journal on Media Management, 15(1), 23-41.

Savar, A. (2013). Content to commerce. New Jersey: Wiley.

Varnali, K. (2017). Customer experience managment. İstanbul: Mediacat Books. 